\title{
Impact of Open Door Policy in Admissions on Retention of ET Students
}

\author{
Virendra K. Varma, Judith W. Grimes, Huiming Wang \\ Missouri Western State College
}

\begin{abstract}
Several institutions of higher education in the United States provide open access to admission to students believing that citizens should have the opportunity to pursue higher education. There are no entrance requirements in terms of ACT or SAT scores. These institutions also offer College 101 or University 101 courses, in addition to developmental courses in mathematics and english, that facilitate the transition of students into college life and help retain them in college. Missouri Western State College (MWSC) is one such open access institution which offers COL 101: Freshman Seminar courses and believes in learning communities, and freshman interest groups (FIG). A FIG is a group of 20-22 MWSC freshmen who enroll in the same cluster of classes during their freshman year on campus. Each FIG creates a supportive and friendly learning community which facilitates the freshman year experience at Missouri Western. This paper describes the impact of student success programs at Missouri Western in retention of engineering technology students, and the impact of teaching a section of COL 101 course. Some statistics are cited that point to success in strategies in retention of ET students at Missouri Western State College.

Introduction

In 1999, Missouri Western State College, was one of seven colleges and universities nationwide to receive the 1999 Retention Excellence Award from Noel-Levitz, an organization specializing in higher education enrollment management, financial aid and student retention. Missouri Western received the award due to its success in retaining students through its Access Plus Program. ${ }^{1}$
\end{abstract}

All across the nation, faculty are experiencing increasingly diverse classrooms. Missouri Western's Access Plus program is a program that helps under-prepared students begin college on the right foot. Because of the college's open door policy for admission, college accepts students of varying abilities. While students are required to take ACT tests to facilitate their placement in appropriate mathematics and english courses, there is no requirement for a minimum score for admission to the college. Access Plus initiative has increased the freshman-to-sophomore retention rate by 10 percent, and the number of freshman on probation has dropped by 13 percent.

Open access institutions, or open-door admission policy institutions, often have high attrition rates; these high rates of student attrition are attributed, in part, to the under-prepared student population. $^{2}$ Missouri Western also has an increasing numbers of honors students. Taking into consideration the impact Missouri Western's Access Plus program has had on the retention rates, it is obvious that there are some steps that can be taken to counteract the challenges of an

"Proceedings of the 2001 American Society for Engineering Education Annual Conference \&Exposition Copyright @ 2001, American Society for Engineering Education” 
open-door policy for admitting students to college. Freshman Interest Groups (FIGs), tutoring, College 101 courses, and an intrusive advising program are some of the elements of the Access Plus program at Missouri Western that have played a major role in the improvement of retention rates of all students including ET students.

This paper addresses some pros and cons of open-door policy, its impact on quality of Engineering and Engineering Technology (ET) education, the quality of engineering and technology graduates, and the overall impact on higher education. There are other institutions like Missouri Western State College which espouse open-door or open enrollment policies. In this paper, however, examples and data pertaining only to Missouri Western are cited.

\section{What is Open-Door Admission Policy?}

Blaine Hudson, in his study of the minimum admission standards at the University of Louisville, Kentucky, wrote, "In a highly stratified yet fluid society, educational institutions contribute either to the reduction of inequality by fostering social mobility---or to the maintenance of inequality by restricting social mobility. American higher educational institutions have tended to serve the latter purpose while espousing the former." 3 Admissions decisions are the responsibility of each public institution, and each public four-year college or university can decide on a mission that best suits itself and the community and the region that it serves.

Missouri Western is a state-supported, open admission four-year institution. The college, based in a metropolitan region, serves both traditional and non-traditional students. It continues to honor its tradition of open access, believing that citizens should have the opportunity to pursue higher education. Open-enrollment, or open admission policy allows the college to admit any State resident with a high school diploma or its equivalent as a first-time, full-time degreeseeking freshman. Open access, however, does not guarantee access to selected programs which may have additional institutionally approved admission criteria. As an example, at Missouri Western, the departments of education and nursing have additional requirements for admission; the department of engineering technology has no additional requirements other than regular admission standards that are applicable to all entering freshmen.

Quality of ET Students and its Relationship to Open Admission Policy

Institutions of higher education that offer engineering technology programs draw their students from several different sources, such as:

1. Vocational technical schools

2. Local industries (these students are mostly non-traditional)

3. High school students (these are the traditional students)

4. Transfer students from engineering schools (these are essentially those students who are either attrition students, or are those students who discover that they really don't like the abstract principles of engineering sciences but instead are tuned to applied aspects of engineering requiring less theoretical derivations)

5. Miscellaneous group of students (students who have no specific major in mind when they join college but get recruited on campus by exposure to engineering technology programs). At Missouri Western, these students come from either 'Undecided', or 'Intended Major'

"Proceedings of the 2001 American Society for Engineering Education Annual Conference \&Exposition Copyright $\odot$ 2001, American Society for Engineering Education” 
categories. 'Intended Major' is a category on Missouri Western's admission application that students check off if they are interested in, or leaning towards an engineering or engineering technology career. These are also the students who most likely add to attrition rates.

The quality of ET students, judging from above, can entail highly varying abilities of students, and poses several challenges for faculty and administration. It can be argued that majority of faculty in an institution with an open-door admission policy, may agree on the merits of open enrollment as a way of giving everybody a chance at higher education but in reality, majority of faculty find themselves ill-prepared to deal with the needs of the under-prepared students. Therefore, special efforts are required to recognize the great importance of the freshman year experience of students, and the transition freshmen and transfer students make to college.

Special efforts under the umbrella of the Missouri Western's Access Plus program in the areas of college orientation, intensive freshman advising, and freshman interest groups (FIGs) have produced the following outcomes:

- A 10 percent increase in freshman to sophomore retention rates

- A 14 percent increase in the retention rate for under-prepared students

- A 42 percent increase in the number of hours students utilized the Center for Academic Support

Under-prepared students are described as those students who have educational deficits requiring some form of remediation. ${ }^{4}$ The focus of Missouri Western's Access Plus program is on creating a teaching and learning environment, which is conducive to student success. The components of Access Plus initiatives include implementation of the following:

- Freshman Year Experience Office - It serves as an information source for students and parents. The office has now undergone a name change to "student success programs" in order to be more inclusive of all students at Missouri Western. The director and staff members also coordinate the advising program for freshmen and the College 101: Freshman Seminar, a 3 credit hour elective course.

- Intensive Freshman Advising Program - It joins all freshman students with specially trained faculty and staff advisors specifically concerned with increasing communication with the students, easing the transition into higher education and helping students develop sound planning skills.

- The "Griffon Edge" - It intensively introduces students to college life through workshops and seminars on a wide range of information including computer instruction, campus safety, personal finance, academic etiquette, cultural diversity, and grading procedures. "Griffon Edge" is held prior to each academic year.

- College 101: Freshman Seminar - It offers students a three-credit course which provides the necessary tools to meet the demands of collegiate academics and campus life.

- Freshman Interest Groups (FIGs) - It clusters two or three classes around a common theme relevant to first-year students and integrates team teaching and advising. A FIG is a group of 20-22 new Missouri Western freshmen who enroll in the same cluster of classes during their first semester on campus. For example, students enrolled in the FIG titled "Express Yourself" (Section 01) take the following courses: ENG 104, COL 101, and THR 113. Each FIG

"Proceedings of the 2001 American Society for Engineering Education Annual Conference \&Exposition Copyright (C) 2001, American Society for Engineering Education” 
creates a supportive and friendly learning community which helps students get off to a good start. The smaller class size also provides students with greater opportunities to talk to faculty about academic and career issues. Only first time entering freshmen are enrolled in FIG clusters. The same students will be taking all of the courses in the FIG cluster. The FIG program is run by Director of Freshman Interest Group.

- Center for Academic Support - It provides comprehensive academic support services in a wide variety of courses. The Center also coordinates study groups and supplemental instruction.

- Center for Excellence in Teaching - It offers faculty important resources as they continue to develop positive teaching techniques which create unique and progressive learning environments for students.

- Unity Services Center - It provides diversity training and multicultural programming as well as support for student athletes.

- "Interpreting Our Heritage" outdoor semester - It allows students to examine cultural, environmental, economic and political issues while traveling throughout the United States and Canada. Participating students earn 15 credit hours in English, physical education and recreation.

Thus, even though students are entering Missouri Western under the open enrollment process, with a wide variation of ACT scores, and some lacking in preparedness, there is a strong developmental structure in place to help all students succeed. A student from a small town in Missouri, wrote, "My experience with Access Plus kept me in school. When I was frustrated and confused, the Freshman Year Experience Office staff helped me find the right support services. Now, I'm showing other students the ropes." Another student wrote, "During my first semester, I was embarrassed to ask for help. Thankfully, I enrolled in a FIG which allowed me to get to know people and feel more comfortable in finding the support I needed."

Of the 95 engineering technology students that were tracked in a recent study at Missouri Western, who intended to major in construction, or electronics, 31.6 percent continued with the ET programs. The remaining 68.4 percent either changed their majors, or are no longer enrolled. This data clearly shows that the category of students with "Intended Majors," needs to be very carefully watched, and dealt with extreme caution.

Conclusion: The ACT Scores, The Open Admission, and the ET Grads

Public institutions of higher education are answerable to the people who support them. If a public academic institution has been created by a local tax levy and the campus was built with money from community approved bonds, it would be extremely difficult to not allow open access to students from the community and the region. It makes good business sense for the institution to serve its base and its clients. The drawbacks of open enrollments can be cured through implementation of programs such as Access Plus, and others like Access Plus. The Access Plus Mission Enhancement Program clearly provides significant results to various Missouri Western constituencies. Faculty, staff and students express excitement and enthusiasm for the program's components. 
The engineering technology students, both traditional and non-traditional, have shown remarkable success pattern during their years at school, and after graduation. In the considered opinions of some faculty, students who are not good test-takers of standardized tests, such as ACT, SAT, etc., have the potential to succeed if given the right environment. The ET graduates of Missouri Western State College are having great success in their professional careers. Some of them, when they were admitted to college, had doubts about their abilities. In a nut shell, it is safe to say that their own desire to continue with the major field of study of their choice, coupled with academic support system of the college, culminated in a successful career. While elementary and secondary education under the American system of education are guaranteed to all americans, no one is guaranteed college education. If open-door admission policy is relevant to the institution, and the region it serves, and if enough positive steps are taken to enhance student retention and success, it is perfectly appropriate to support open enrollment policies and procedures. In that context, Missouri Western's mission to honor its tradition of open access, believing that citizens should have the opportunity to pursue higher education, is justified. Access Plus at Missouri Western is a clear indicator of such success because it continues to serve its students and faculty in the spirit of excellence in education.

Bibliography

1. Varma, V. K., Grimes, J., \& Wang H. "Exploring the Recruitment \& Retention Paradigm: What Works \& What Doesn't." Proceedings of 1999 ASEE Annual Conference \& Exposition, Charlotte, NC, June 20-23, 1999.

2. Oliver, C. "The Community Open-Door Philosophy: What Negative Outcomes have Developed?" 1996. New York (ERIC Document Reproduction Service No. ED 338 345)

3. Hudson, B. J. “The Impact of Minimum Admission Standards: 1986-1989.” Louisville, KY. Louisville University Press. (ERIC Document Reproduction Service No. ED 334 917)

4. Pitts, J. M., White, Jr., W. G., \& Harrison, A. B. "Student Academic Under-preparedness: Effects on Faculty." The Review of Higher Education, 22(4), 343-365, 1990.

VIRENDRA K. VARMA

Virendra K. Varma, Ph.D., P.E., F. ASCE, is professor of construction, and an ex-chair of the Department of Engineering Technology at Missouri Western State College. He has been teaching COL 101: Freshman Seminar courses since 1993.

JUDITH GRIMES

Judith Grimes, Ph.D., is Director of Student Success Programs at Missouri Western State College.

HUIMING WANG

Huiming Wang, Ed.D., is currently a research analyst for the University of Missouri System, and formerly directed research on the Access Plus program at Missouri Western State College. 